Arq. Bras. Med. Vet. Zootec., v.66, n.3, p.769-777, 2014

\title{
Cryoprotection effectiveness of low concentrations of natural and lyophilized LDL (low density lipoproteins) on canine spermatozoa
}

\author{
[Eficiência de baixas concentrações de lipoproteínas de baixa densidade natural e \\ liofilizada na crioproteção de espermatozoides caninos] \\ M.M. Neves ${ }^{1}$, L.G.D. Heneine ${ }^{2}$, M. Henry ${ }^{1 *}$ \\ ${ }^{1}$ Escola de Veterinária - Universidade Federal de Minas Gerais - UFMG - Belo Horizonte, MG \\ ${ }^{2}$ Fundação Ezequiel Dias - Funed - Belo Horizonte, MG
}

\begin{abstract}
The aim of this study was to evaluate the use of low concentrations of natural and lyophilized low density lipoprotein (LDL) from hen's egg yolk for cryopreservation of canine semen. Different ammonium sulphate concentrations were tested to extract LDL from egg yolk. The yolk was centrifuged, and LDL was isolated using 10, 20, 40, 45, or 50\% ammonium sulphate solution (ASS). The LDL-rich floating fraction was collected for chemical characterization. Dry matter content was lowest $(\mathrm{P}<0.05)$ in the LDL extracted with the 50\% ASS. The purification of LDL increased in association with increasing ammonium sulphate concentrations. SDSPAGE showed that the 50\% ASS solution yielded a purer fraction of LDL from egg yolk. For semen cryopreservation, TRIS extender was used replacing $20 \%$ egg yolk (control) by natural or lyophilized LDL using 1,2 , and $3 \%(\mathrm{w} / \mathrm{v})$. Semen was centrifuged $(755 \mathrm{Xg}$ for $7 \mathrm{~min}$ ), diluted with one of the extenders, packed into $0.5 \mathrm{~mL}$ straws $\left(100 \times 10^{6} \mathrm{sperm} / \mathrm{mL}\right)$, and placed in a programmable cryopreservation machine. Thawed semen $\left(37^{\circ} \mathrm{C} / 30 \mathrm{~s}\right)$ was analyzed for sperm motility, morphology, and by the hypoosmotic and epifluorescence tests (CFDA/ PI). Natural LDL extracted with 50\% ASS was as effective as whole egg yolk to preserve canine frozen sperm when using low concentrations. The lyophilized LDL, mainly in the two higher concentrations tested (2 and 3\%), was unsuitable to maintain the effectiveness of the LDL cryoprotective effect on dog sperm.
\end{abstract}

Keywords: egg Yolk, LDL extraction, ammonium sulphate, dog, semen

\section{RESUMO}

O objetivo deste estudo foi avaliar o uso de baixas concentrações da lipoproteína de baixa densidade (LBD) extraída da gema do ovo de galinha, nas formas natural e liofilizada, na criopreservação do sêmen canino. Diferentes concentrações de sulfato de amônio também foram testadas na extração da LBD da gema do ovo. A gema foi centrifugada, sendo a LBD isolada usando-se solução saturada de sulfato de amônio (SSA) nas concentrações de 10, 20, 40, 45 e 50\%. A fração rica em LBD foi coletada para caracterização química. $O$ conteúdo de matéria seca foi menor $(P<0,05)$ na LBD extraída com SSA 50\%. A pureza da LBD melhorou à medida que se aumentou a concentração de SSA utilizada. SDS-PAGE mostrou que a SSA 50\% produziu uma fração mais pura de LBD oriunda da gema do ovo. Para o congelamento de sêmen, o meio diluidor TRIS teve a gema do ovo a $20 \%$ (controle) substituída pela $L B D$ a 1,2 e $3 \%$ (p/v), nas formas natural e liofilizada. $O$ sêmen foi centrifugado (755xg por $7 \mathrm{~min}$ ), diluído em um dos meios diluidores em teste e envasado em palhetas de $0,5 \mathrm{~mL}\left(100 \times 10^{6} \mathrm{sptz} / \mathrm{mL}\right)$, sendo congelado em máquina de congelamento programável. O sêmen descongelado $\left(37^{\circ} \mathrm{C} / 30 \mathrm{~s}\right)$ foi analisado quanto à motilidade e à morfologia espermática e nos testes hiposmótico e de epifluorescência (DACF/IP). A LBD natural extraída com SSA $50 \%$ foi tão eficiente quanto a gema do ovo na preservação do espermatozoide canino congelado nas baixas concentrações testadas. A LBD liofilizada, principalmente as duas maiores concentrações (2 e 3\%), não foi adequada para manter o efeito crioprotetor da LBD sobre o espermatozoide canino.

Palavras-chave: gema do ovo, extração da LBD, sulfato de amônio, cão, sêmen

Recebido em 15 de setembro de 2012

Aceito em 18 de dezembro de 2013

*Autor para correspondência (corresponding author)

E-mail: henrym@ufmg.br 


\section{INTRODUCTION}

The cryoprotective effect of egg yolk on cooled and frozen sperm from domestic animals has been primarily attributed to low density lipoproteins (LDL; Pace and Graham, 1974). Attempts have been made to use natural LDL in lieu of egg yolk in semen extenders (Foulkes, 1977), with promising results (Moussa et al., 2002; Hu et al., 2010). The extraction of LDL from egg yolks facilitates the use of specific amounts of defined substances, thereby excluding undesirable components, eg.: high density lipoprotein (Demianowicz and Strzezek, 1996), which are deleterious to semen cryopreservation.

Density gradient ultracentrifugation has frequently been used for the purification of egg yolk lipoproteins, but it is too slow and inefficient for commercial use. Moussa et al. (2002) proposed an easy, quick, and efficient method to extract LDL, based on the use of $40 \%$ of ammonium sulphate. In preliminary trials (unpublished), we were not able to replicate their electrophoretic profile. Indeed, some factors might alter LDL purity and yield, such as temperature, quantity of ammonium sulphate used and the way it is added (Harris, 1992).

The use of LDL instead of egg yolk in seminal extenders improved canine spermatozoa survival following the freezing thawing process (Bencharif et al., 2008; Varela Junior et al., 2009), and when associated with Equex (Bencharif et al., 2010a) or glutamine (Bencharif et al., 2010b). Those studies added LDL in the extenders at different concentrations: 6,8 , and $10 \%$ (v/v; Varela Junior et al., 2009), and 4\% (11g LDL) to $8 \%(22 \mathrm{~g})$ and $10 \% \quad(27.5 \mathrm{~g}$; Bencharif et al., 2008). They found different results regarding the best concentration to be used for $\operatorname{dog}$ semen, being $8 \%$ and $6 \%$, respectively. However, there are still few studies testing different LDL concentrations to be added in seminal extenders for the cryopreservation of canine spermatozoa; moreover, there is no information about the minimum concentration of LDL capable to maintain the sperm viability. Therefore, the first aim of the present study was to determine the optimal concentration of ammonium sulphate solution for the extraction of LDL from egg yolk, and the second was to determine the cryoprotection effectiveness of low concentrations of LDL added to canine semen extender either in natural or lyophilized form.

\section{MATERIALS AND METHODS}

Fresh eggs $(n=50)$ were thoroughly cleaned and rinsed with distilled water. The egg shells were cracked and the yolk and albumen were separated. The viteline membrane was perforated, the egg yolk was aspirated, diluted 1:2 (v:v) in $0.17 \mathrm{M}$ sodium chloride solution, homogenized with a magnetic stirrer for $1 \mathrm{~h}$ at $4^{\circ} \mathrm{C}$, and $\mathrm{pH}$ was measured. The homogenate was then centrifuged $\left(11,400 \mathrm{~g}\right.$ for $45 \mathrm{~min}$ at $4{ }^{\circ} \mathrm{C}$; all centrifugations subsequently described used these conditions). The pellet (granular portion of the egg yolk) was discarded and the supernatant was again centrifuged. The $\mathrm{pH}$ of the plasma (supernatant obtained after the second centrifugation) was adjusted to 8.7, using a $1 \mathrm{M}$ sodium hydroxide solution.

Ammonium sulphate solution (ASS) at 10, 20, 40,45 , and $50 \%$ was added dropwise (20 to $30 \mathrm{~min})$ to the cooled plasma $\left(4^{\circ} \mathrm{C}\right.$; Harris, 1992). The mixture was maintained at $4{ }^{\circ} \mathrm{C}$, with continuous stirring, for another hour. The mixture was then centrifuged and the supernatant dialyzed in cellophane membrane (NMCO: 1214,000 Da; Spectra/Por, Rancho Dominguez, Canada) against MilliQ water for $40 \mathrm{~h}$, followed by centrifugation of the dialysis membrane content. The upper floating part containing the LDL was carefully withdrawn from the centrifuge tube, avoiding contamination by the fluid portion located at the bottom of the tube. The extracted LDL was divided into two parts. The first part was preserved at $-20^{\circ} \mathrm{C}$ until analysis, while the other part was lyophilized in sealed plastic tubes and stored at $-20^{\circ} \mathrm{C}$ until its use.

Protein composition of LDL extracted was analysed by SDS-PAGE. The stacking and running gels held 4 and $12.5 \%$ polyacrylamide (BioRad Laboratory, Hercules, USA) respectively. Approximately $25 \mu \mathrm{g}$ of proteins were set on the gel. Electrophoretic migration was performed at 200 watts, $48 \mathrm{~mA}$ for $50 \mathrm{~min}$ at $21-23^{\circ} \mathrm{C}$ ). Molecular weights of proteins and apoproteins were determined using $R f$ of standard proteins (RPN800V, Amersham 
Bioscience, Sweden): 250, 160, 105, 75, 50, 35, $30,25,15$, and 10KDa. Polyacrylamide gel was stained with Comassie Blue. The electrophoretic profile was used to determine which ammonium sulphate solution treatment yielded the purer LDL fraction.

Dry matter contents of the whole egg yolk (control) and of the LDL extracted by different ASS concentrations were obtained after $24 \mathrm{~h}$ incubation in a muffle furnace at $104^{\circ} \mathrm{C}$ (Moussa et al., 2002). The lipid content was determined by the Soxhlet method (Lara et al., 1976), and the protein content was determined as described by Lowry et al. (1951).

Ejaculates from four dogs aging 2 and 3 years (three Labrador Retrievers and one Shar-pei) were collected by digital manipulation. Ejaculates were diluted in a control extender indicated for canine semen (Schäfer-Somi et al., 2006) containing Tris $(3.026 \mathrm{~g})$, citric acid monohydrate $(1.7 \mathrm{~g}), \quad$ fructose $\quad(1.25 \mathrm{~g})$, estreptomicin $(0.1 \mathrm{~g})$, glycerol $(5 \mathrm{~mL})$, and egg yolk $(\mathrm{v} / \mathrm{v})$ in bidistilled water $(100 \mathrm{~mL} \mathrm{qsp} ; \mathrm{pH}$ $6.97 ; 1151 \mathrm{mOsm} / \mathrm{L})$. The other extenders were composed of LDL (extracted with 50\% ASS), in replacement of whole egg yolk, using two forms (natural and lyophilized LDL) and three different concentrations, $1 \%, 2 \%$, and $3 \% \quad(\mathrm{w} / \mathrm{v})$. Lyophilized LDL was firstly dissolved in $0.1 \mathrm{M}$ phosphate buffer with $1 \%$ Tween 20 to be added to the Tris extender.

The experimental design was set up as two $4 \times 4$ latin squares (Sampaio, 2001), one containing a control treatment plus natural LDL (n-LDL; three concentrations) and the other testing the lyophilized LDL (1-LDL; three concentrations) plus a control treatment. The ejaculate of each dog was divided into two equal parts, one part to be used in each square. Then all treatments were applied on the same day (four dogs, four ejaculates, two treatment/ejaculate).

Progressive motility was evaluated immediately after semen collection. Only ejaculates with at least $80 \%$ progressive motility and $80 \%$ normal morphology were used in the study (Johnston et al., 2001). The ejaculate was divided into two equal parts and diluted in Glucose-EDTA extender (Martin et al., 1979; pH 6.7; $429 \mathrm{mOsm} / \mathrm{L})$ for centrifugation $(755 \mathrm{X} \mathrm{g}$ for $7 \mathrm{~min})$ at room temperature. Each pellet was diluted with one extender to be tested (final concentration, $100 \times 10^{6} \mathrm{sperm} / \mathrm{mL}$ ). The semen was packed into $0.5 \mathrm{~mL}$ straws, immediately placed in a programmable cryopreservation machine (TK3000, Tetakon, Brazil) and cooled at a rate of $-0.5^{\circ} \mathrm{C} / \mathrm{min}$, from 25 to $5^{\circ} \mathrm{C}$, equilibrated for $1 \mathrm{~h}$ at $5^{\circ} \mathrm{C}$, and frozen at a rate of $-20^{\circ} \mathrm{C} / \mathrm{min}$, from 5 to $-120^{\circ} \mathrm{C}$. Then straws were immersed and preserved in liquid nitrogen for at least one week before examining; straws were submerged in a water bath $\left(37^{\circ} \mathrm{C} / 30 \mathrm{~s}\right)$ for semen thawing.

Post-thaw sperm motility was analyzed with computer-assisted semen analysis (CASA; Hamilton Thorne Biosciences ${ }^{\circledR}$, USA). The equipment was adjusted for fresh canine semen; $10 \mu 1$ of sample from each straw (three straws per treatment) was examined and five fields were randomly chosen. The following end points were determined: total motility (TM, \%), progressive motility (PM, \%), path velocity (VAT, $\mu \mathrm{m} / \mathrm{s}$ ), progressive velocity (VSL, $\mu \mathrm{m} / \mathrm{s}$ ), curvilinear velocity (VCL, $\mu \mathrm{m} / \mathrm{s})$, straightness $\quad(\mathrm{STR}=$ (VSL/VAP) X 100), and linearity (LIN= (VSL/VCL) X 100).

Sperm morphology was assessed under differential phase interference microscopy at a magnification of 400x (Nikon, model 80i) and the hypo-osmotic swelling test (HOST; KumiDiaka, 1993) was performed using a fructose solution (60 mOsmol/L). Structural membrane integrity was evaluated by epifluorescence test using carboxifluorescein diacetate (CFDA) and propidium iodate (PI; Harrison and Vickers, 1990).

Analysis of variance (ANOVA) was used to compare the LDL obtained after extraction using different concentrations of ammonium sulphate solution (dry matter, lipid and protein contents of LDL), and means were compared with the Tukey test. LDL purity was evaluated using the number of stained bands in the SDS-PAGE profile. Data from the progressive motility was analyzed by the Kruskal-Wallis test and mean comparisons were obtained by the Dunn test. Data from the morphology analysis, the reactive spermatozoa to hypoosmotic test and the structural sperm membrane integrity were analyzed by ANOVA and the Tukey test. For all analysis, $\mathrm{P}<0.05$ was considered significant. All statistical analyses were performed with the $\mathrm{SAS}^{\circledR}$ program 
(Statistical Analysis System, Cary, NC, USA), and the values were expressed by means and standard deviation (SD).

\section{RESULTS}

Two distinct fractions were present at the end of each extraction. The floating fraction containing LDL was a paste with a distinct yellow color. The second fraction was a fluid located at the bottom of the tube showing a turbid yellowish color, when $10 \%$ and $20 \%$ ASS concentrations were used. When higher ASS concentrations were used the fluid located at the bottom was more transparent.

Dry matter, lipid content and protein concentration of whole egg yolk and of LDL extracted with different concentration of ASS are shown in Table 1. Dry matter content was lowest $(\mathrm{P}<0.05)$ in the LDL extracted with $50 \%$ saturated solution. LDL isolated with the $10 \%$ saturated solution had the lowest value for fresh lipid content and highest value for protein content $(\mathrm{P}<0.05)$. Values for lipid (fresh matter) and protein content were not different $(\mathrm{P}>0.05)$ for LDL extracted with $20 \%$ to $50 \%$ ASS. Lipid content of dry matter was higher following extraction with $45 \%$ and $50 \%$ than with $10 \%$ and $20 \%$ ASS $(\mathrm{P}<0.05)$.

A purer fraction of LDL was obtained when extraction was done using 50\% ASS (Fig. 1; SDS-PAGE). Six stained bands with approximate molecular weights of 15, 18, 30, 37, 45 , and $149 \mathrm{KDa}$ were obtained.

Table 1. Characterization of low density lipoprotein (LDL) fraction extracted with different ammonium sulphate concentrations

\begin{tabular}{lcccccc} 
& \multicolumn{5}{c}{ Ammonium sulphate concentration (\%) } \\
\cline { 2 - 7 } & Egg yolk & 10 & 20 & 40 & 45 & 50 \\
\hline DM (\%) & $51 \pm 0.1 \mathrm{~b}$ & $72 \pm 0.1 \mathrm{a}$ & $61 \pm 0.3 \mathrm{a}$ & $41 \pm 0.2 \mathrm{c}$ & $44 \pm 0.7 \mathrm{c}$ & $39 \pm 0.3 \mathrm{~d}$ \\
Lipids (\% FM) & $30 \pm 2.8 \mathrm{a}$ & $18 \pm 0.9 \mathrm{~b}$ & $27 \pm 0.8 \mathrm{a}$ & $27 \pm 0.3 \mathrm{a}$ & $32 \pm 1 \mathrm{a}$ & $29.5 \pm 0.5 \mathrm{a}$ \\
Lipids (\% DM) & $59 \pm 5.5 \mathrm{~b}$ & $25 \pm 1.3 \mathrm{c}$ & $44 \pm 1.3 \mathrm{~b}$ & $66 \pm 0.8 \mathrm{ab}$ & $72 \pm 2.3 \mathrm{a}$ & $75 \pm 1.4 \mathrm{a}$ \\
Proteins (mg/mL) & $9.2 \pm 1.8 \mathrm{a}$ & $11 \pm 0.3 \mathrm{a}$ & $5.1 \pm 0.6 \mathrm{~b}$ & $5 \pm 3.8 \mathrm{~b}$ & $4.1 \pm 4.6 \mathrm{~b}$ & $5.8 \pm 3.7 \mathrm{~b}$ \\
\hline
\end{tabular}

Mean \pm SD. Within a row, means without a common superscript differed $(\mathrm{P}<0.05)$ by the Tukey test. DM - dry matter, FM - fresh matter.

The mean value of progressive motility on fresh semen was $81.9 \pm 3 \%$. Total and progressive sperm motility in frozen-thawed samples was similar $(\mathrm{P}>0.05)$ among control and natural LDL treatments (Fig. 2), but higher $(\mathrm{P}<0.05)$ than that obtained when sperm was cryopreserved with $1 \%$ 1-LDL. The mean values of total and progressive motility were less than $1 \%$ l-LDL when $2 \%$ or $3 \% 1-\mathrm{LDL}$ was used.

The mean post-thaw sperm velocities for each extender are shown in Table 2. There were differences $(\mathrm{P}<0.05)$ among treatments on average path (VAP), straight line (VSL), and curvilinear velocities (VCL). Lower values were obtained when 2 and 3\% l-LDL were used. The percentages of cells that showed straightness was highest $(\mathrm{P}<0.05)$ in samples cryopreserved in the control extender and in extenders containing natural LDL and 1\% 1-LDL (Fig. 3). The extenders containing 2 and 3\% l-LDL showed the worst percentages of cells for linearity parameter $(\mathrm{P}<0.05)$.

Characteristics of sperm structure and function of fresh and thawed samples are shown in Table 3. For all end points evaluated in thawed semen, there were no differences $(\mathrm{P}>0.05)$ in sperm frozen using the control extender and extenders containing either one of the three n-LDL concentrations. However, when 1-LDL was used, regardless of concentrations, means for normal morphology and integrity membranes of sperm were lower than means obtained for $n-L D L$ extenders. 


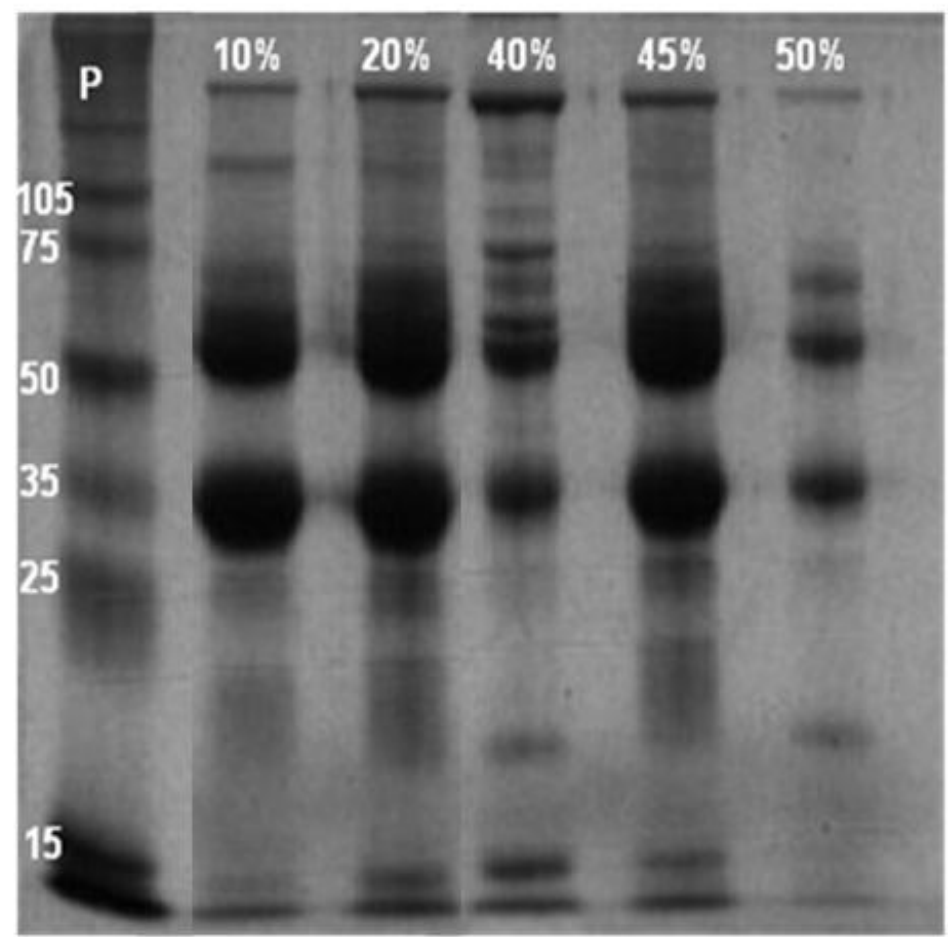

Figure 1. Polyacrylamide gel electrophoresis (SDS-PAGE; stained with Comassie blue) of molecular weight (KDa) of standard solution (P) and low density lipoproteins extracted using either 10, 20, 40, 45, or $50 \%$ ammonium sulphate solutions.

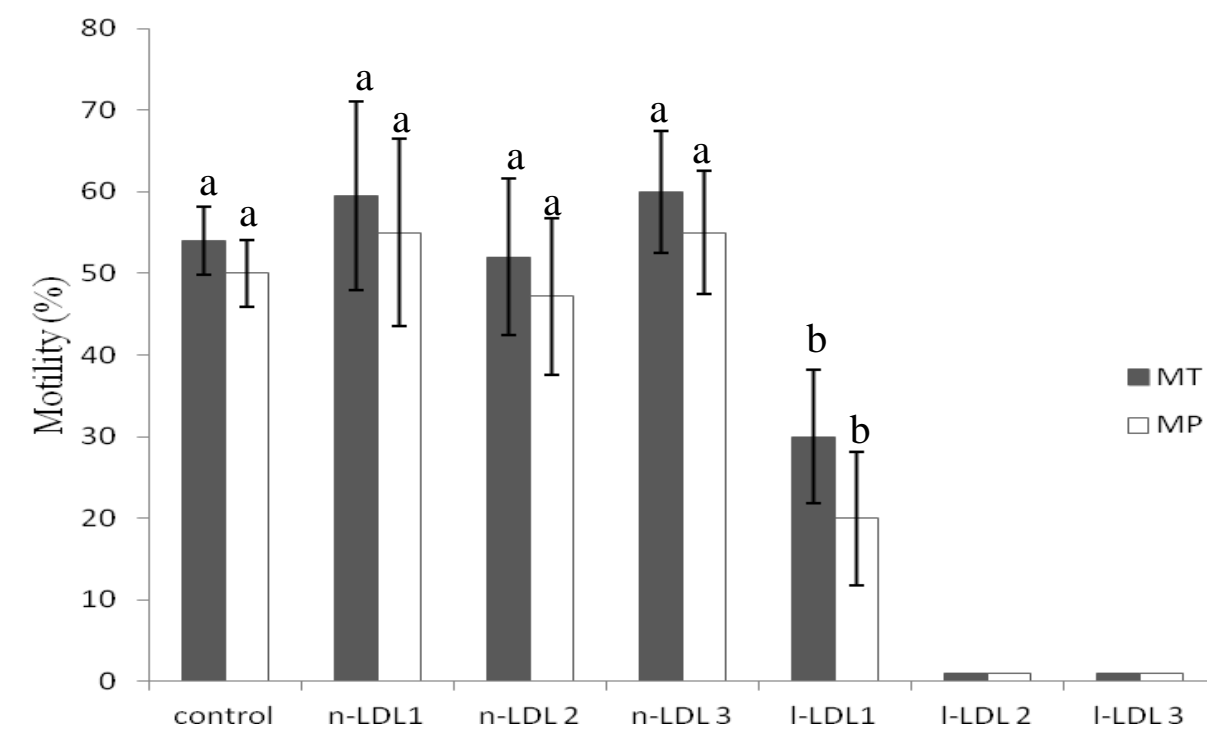

Fig. 2. Mean \pm SD percentage of total $(\mathrm{TM})$ and progressive motility $(\mathrm{PM})$ of frozen- thawed canine cryopreserved sperm with natural (n) or lyophilized (l) - LDL (in lieu of egg yolk). The control extender was Tris $+20 \%$ egg yolk, $1-1 \%(\mathrm{w} / \mathrm{v}), 2-2 \%(\mathrm{w} / \mathrm{v}), 3-3 \%(\mathrm{w} / \mathrm{v}){ }^{\mathrm{a}, \mathrm{b}}$ Within an end point (TM and PM), means without a common superscript differed $(\mathrm{P}<0.05)$ by Dunn's test. 
Table 2. Path velocity, progressive velocity and curvilinear velocity of frozen-thawed canine cryopreserved sperm with natural and lyophilized low density lipoprotein in lieu of $20 \%$ egg yolk (control extender)

\begin{tabular}{cccc}
\hline Treatment & VAP $(\mu \mathrm{m} / \mathrm{s})$ & VSL $(\mu \mathrm{m} / \mathrm{s})$ & VCL $(\mu \mathrm{m} / \mathrm{s})$ \\
\hline Control & $34.6 \pm 2.7 \mathrm{~b}$ & $24.8 \pm 2.8 \mathrm{~b}$ & $53.7 \pm 4.6 \mathrm{~b}$ \\
n-LDL 1\% (w/v) & $43.3 \pm 2.7 \mathrm{a}$ & $33.4 \pm 3.1 \mathrm{a}$ & $71.5 \pm 2.6 \mathrm{a}$ \\
$\mathrm{n}-\mathrm{wDL} \%(\mathrm{w} / \mathrm{v})$ & $49 \pm 9.3 \mathrm{a}$ & $39.1 \pm 8.1 \mathrm{a}$ & $80.5 \pm 13.9 \mathrm{a}$ \\
$\mathrm{n}-\mathrm{LDL} \mathrm{3 \%}(\mathrm{w} / \mathrm{v})$ & $48.8 \pm 4.1 \mathrm{a}$ & $37.5 \pm 1.5 \mathrm{a}$ & $79.6 \pm 7.2 \mathrm{a}$ \\
l-LDL 1\%(w/v) & $17.9 \pm 5.9 \mathrm{~b}$ & $13.3 \pm 5.5 \mathrm{~b}$ & $35.4 \pm 6.1 \mathrm{c}$ \\
l-LDL 2\% (w/v) & $5.1 \pm 2.3 \mathrm{c}$ & $2.6 \pm 1.4 \mathrm{c}$ & $16.6 \pm 3.0 \mathrm{~d}$ \\
l-LDL 3\% (w/v) & $5.8 \pm 2.9 \mathrm{c}$ & $3.2 \pm 1.9 \mathrm{c}$ & $17.2 \pm 7.3 \mathrm{~d}$ \\
\hline
\end{tabular}

Mean \pm SD, ${ }^{\text {a-d }}$ Within a columnn, means without a common superscript differed $(\mathrm{P}<0.05)$ by Dunn's test. Control extender - Tris-citric acid-fructose plus $20 \%$ (v/v) egg yolk. n-LDL - natural low density lipoproteins, 1-LDL lyophilized low density lipoproteins. VAP - Path velocity, VSL - progressive velocity, VCL - curvilinear velocity.

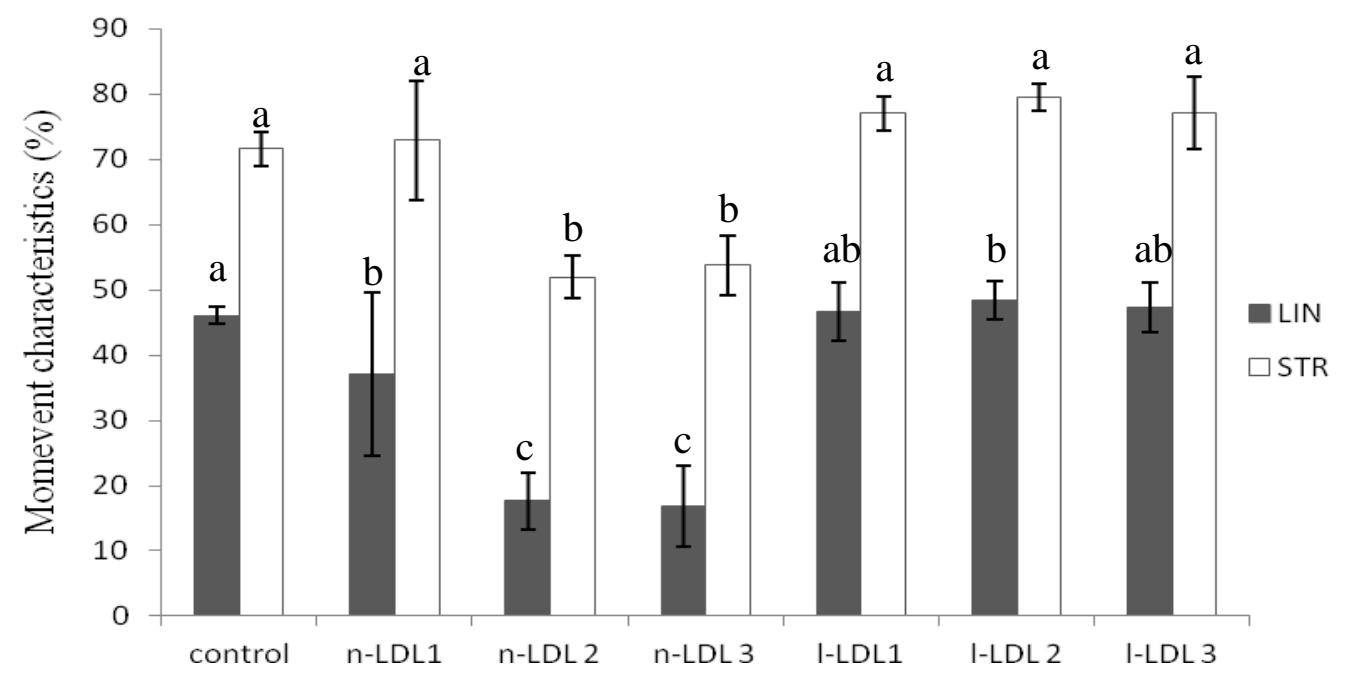

Fig. 3. Mean \pm SD linearity (LIN) and straightness (STR) of frozen- thawed canine sperm cryopreserved with natural (n) or lyophilized (l) low density lipoproteins (LDL; in lieu of egg yolk). The control extender was Tris-citric-fructose $+20 \%$ egg yolk, $1-1 \%(\mathrm{w} / \mathrm{v}), 2-2 \%(\mathrm{w} / \mathrm{v}), 3-3 \%(\mathrm{w} / \mathrm{v}) .{ }^{\mathrm{a}, \mathrm{b}}$ Within an end point (LIN or STR), means without a common superscript differed $(\mathrm{P}<0.05)$ by Dunn's test.

Table 3. Morphophysiological characterization of fresh and frozen canine spermatozoa in extenders containing different concentrations of natural and lyophilized low density lipoproteins

\begin{tabular}{ccccc}
\hline Treatments & AA $(\%)$ & NMS $(\%)$ & HOST $(\%)$ & SMI (\%) \\
\hline Fresh semen & $0.6 \pm 0.1$ & $87.5 \pm 7.2$ & $92 \pm 2.7$ & - \\
Control & $15.2 \pm 10.9 \mathrm{a}$ & $57 \pm 10.6 \mathrm{a}$ & $54 \pm 6.7 \mathrm{a}$ & $56 \pm 8.1 \mathrm{a}$ \\
n-LDL 1\% (w/v) & $11 \pm 4.7 \mathrm{a}$ & $47 \pm 7.2 \mathrm{a}$ & $55 \pm 11.1 \mathrm{a}$ & $53 \pm 6.5 \mathrm{a}$ \\
n-LDL 2\% (w/v) & $20 \pm 8.3 \mathrm{a}$ & $42 \pm 9.9 \mathrm{ab}$ & $58 \pm 13.7 \mathrm{a}$ & $48 \pm 3.1 \mathrm{a}$ \\
n-LDL 3\% (w/v) & $14 \pm 7.9 \mathrm{a}$ & $51 \pm 7.8 \mathrm{a}$ & $59 \pm 5.8 \mathrm{a}$ & $51 \pm 10.7 \mathrm{a}$ \\
l-LDL 1\% (w/v) & $26 \pm 13.9 \mathrm{ab}$ & $30 \pm 13.1 \mathrm{~b}$ & $43 \pm 8.7 \mathrm{a}$ & $38 \pm 16 \mathrm{a}$ \\
l-LDL 2\% (w/v) & $27 \pm 5.4 \mathrm{ab}$ & $34 \pm 6.2 \mathrm{~b}$ & $7 \pm 3.4 \mathrm{~b}$ & $1.7 \pm 1.1 \mathrm{~b}$ \\
l-LDL 3\% (w/v) & $41 \pm 12.3 \mathrm{~b}$ & $29.2 \pm 4 \mathrm{~b}$ & $6 \pm 1.7 \mathrm{~b}$ & $9 \pm 9.5 \mathrm{~b}$ \\
\hline
\end{tabular}

${ }^{\mathrm{a}-\mathrm{d}}$ Within a column, means without a common superscript differed $(\mathrm{P}<0.05)$ by the Tukey test. Control extender - Tris $+20 \%$ egg yolk. n-LDL - natural low density lipoproteins, 1-LDL - lyophilized low density lipoproteins. AA abnormal acrosome, NMS - normal morphology of sperm, HOST - reactive sperm for hypo-osmotic swelling test, $\mathrm{SMI}$ - structural membrane integrity $\left(\mathrm{CFDA}^{+} / \mathrm{PI}^{-}\right.$test). 


\section{DISCUSSION}

The LDL extraction done here followed the method described by Moussa et al. (2002) with two modifications: a higher centrifugal force and a solution of ammonium sulphate applied as a solution instead of the solid form. These modifications resulted in a more efficient and replicable LDL extraction. Fractionation of proteins is usually done by adding neutral salts at $4^{\circ} \mathrm{C}$. In general, ammonium sulphate is added in either solid or dissolved forms. To minimize the salting out effects and precipitation of unwanted substances (Harris, 1992), ammonium sulphate solution was added dropwise; moreover, changes in the concentration of the ammonium sulphate solution significantly affected LDL purification. The dry matter content of the supernatant (lipoprotein) decreased as the concentration of the ammonium sulphate solution increased, consistent with increased precipitation of proteins, including phosvitins and livetins (egg yolk plasma components), resulting in a highly purified LDL fraction (supernatant) with low amount of proteins. Protein content of the extracted LDL was similar when ammonium sulphate solutions were $\geq 20 \%$, suggesting that a solution of at least $20 \%$ is required to remove proteins.

Precipitation using 50\% of ammonium sulphate solution was the most suitable concentration to extract LDL when compared to 10, 20, 40 and $45 \%$. With saturation levels below $50 \%$ the subnatant was still turbid, indicating that livetins were not adequately removed. A higher amount of bands and gradative decrease in band density from 20 to $50 \%$ ammomium sulphate solution used during the extraction supported this assertion. However, none of the extracts yielded an electrophoretic profile that matched those reported by Moussa et al. (2002), extracted with $40 \%$ ammonium sulphate. The only similar protein band between studies was the $15 \mathrm{KDa}$, which corresponded to the apoprotein-B of the LDL. This band was present following extraction with $40 \%, 45 \%$, or $50 \%$ ammonium sulphate solutions. The fact that less molecular weight bands where observed in the LDL extracted using a 50\% ammonium sulphate solution indicated a more purified LDL sample.

Molecular weights of the extracted LDL varied between those observed in the present study and those reported by Moussa et al. (2002), Anton et al. (2003), and Jolivet et al. (2006). Several factors may have contributed to this apparent difference. Ambient temperature can alter the degree of saturation of a solution. Variations could also result from reagent source and inherent differences in egg yolk composition; the latter varies with the interval from time of laying and use, environmental conditions, diet, genetic line, and bird species (Evans et al., 1969).

Considering the cryoprotective effectiveness obtained with the natural LDL extracted by $50 \%$ ammonium sulphate solution, it was evident that LDL was as efficient as whole egg yolk to preserve canine sperm viability post thaw at any of the three concentrations tested. Total and progressive motility, percentage of acrosome abnormality in sperm, morphology of sperm, reactivity to HOST, and preservation of structural sperm membrane integrity was similar among the extenders.

Many studies have reported similar effectiveness to preserve sperm submitted to the freezing process between natural LDL and egg yolk extenders (Moustacas et al., 2011 in ram), and better results with LDL instead of egg yolk in extenders (Bencharif et al., 2008; Varela Junior et al., 2009; Hu et al., 2010). The present study demonstrated that low concentrations of LDL can also be used to support the canine sperm viability after the freezing-thawing process.

Based on the kinetic attributes of sperm post thaw, there was a variation on the pattern of protection of low concentrations of natural LDL in comparison to whole egg yolk. While all natural LDL concentrations preserved VAP, VSL, and VCL better than the egg yolk extender, egg yolk was more capable to preserve LIN and STR than $2 \%$ and $3 \%$ natural LDL. It could mean that $\mathrm{n}$-LDL has a different potential to cryopreserve some kinetic parameters. Moussa et al. (2002) demonstrated that bovine sperm frozen thawed in extender containing various concentrations of LDL had VAP, VSL, and VCL similar to those obtained with an extender containing $20 \%$ whole egg yolk, though the LDL extenders were better for sperm motility. Therefore, the variation of the protective pattern does not necessarily mean a problem in the concentration used; even so, we suggest that the 
concentrations used here should be applied for cryopreservation of canine spermatozoa.

Although positive results were reached for the natural LDL, the same was not observed for lyophilized samples as prepared herein. Sperm motility post thaw was inferior to that observed using n-LDL or $20 \%$ whole egg yolk. A similar preparation of 1-LDL was used by Moustacas et al. (2011) to cryopreserve ram spermatozoa, and 1-LDL was also ineffective in protecting ram sperm during the freezing thawing process.

The decline in the functional and structural integrity of the sperm membranes was least severe when $3 \%$ l-LDL was used in comparison to 1 and $2 \%$ l-LDL. When $1 \%$ and 2\% l-LDL was used, the incidence of acrosome abnormality and abnormal morphology of sperm were also less than $3 \%$. The variation in the protective ability of some movement characteristics demonstrated for the n-LDL extender was also observed for the three concentrations of 1-LDL. Lyophilized LDL was incapable to sustain the VAP, VSL, and VCL in comparison with n-LDL, but the 1-LDL1\% was as capable as the egg yolk extender to maintain these parameters, besides STR and LIN. Moreover, all the 1-LDL extenders showed better results than n-LDL $2 \%$ and $3 \%$ for the last two kinetic attributes.

Some factors might be related to the results obtained for the 1-LDL extenders, such as the molecular destabilization of LDL during the freeze-drying process, the storage temperature, or the solvent used for its reconstitution. Regarding the first one, Watson (1981) reported that the freeze-drying process could cause loss of LDL activity, due to denaturation resulting from the removal of water. However, Obara et al. (2006) mentioned that the water present in the egg yolk may function as a substrate or medium for many lipid oxidation reactions, so the lyophilizing could be an interesting long term method for storing LDL. The storage temperature has been studied in our laboratory, and our preliminary results showed that $-20{ }^{\circ} \mathrm{C}$ did not influence the bioactivity of LDL, neither in natural or lyophilized forms (unpublished data). Regarding the third factor, we did not find any information regarding the possible deleterious effect of $0.1 \mathrm{M}$ phosphate buffer with $1 \%$ Tween 20 on the viability aspects of frozen sperm. Keyhani and Story (1973), mentioned by
Jones (1997) observed that rabbit epidydimal sperm, when treated with hypotonic phosphate buffer, retained both mitochondrial membranes but the plasma membrane had been disrupted. Regarding the Tween 20, it is a medium detergent with no-ionic characteristics, which preserve the biological structure and membrane activity without dissolving great quantities of proteins and phospholipids from the human erytrocite membrane (Grant and Hjertén, 1977). It has never been applied as a detergent in sperm cryopreservation protocols. Tween 20 may have had deleterious effects on sperm such as desnaturing proteins of the plasmatic membrane or may have provoked other injuries, which lead to disrupted membrane integrity.

\section{CONCLUSIONS}

In conclusion, the modification brought to the Moussa's technique improved LDL extraction, and the natural LDL produced by this method was as efficient as whole egg yolk to protect canine sperm during cryopreservation. The amount of $1 \%, 2 \%$, and $3 \%$ is sufficient to protect canine sperm during cryopreservation. The lyophilization of LDL used was inefficient to preserve the protectiveness of the LDL to freeze sperm.

\section{ACKNOWLEDGEMENTS}

We thank FAPEMIG for their financial support.

\section{REFERENCES}

ANTON, M.; MARTINET, V.; DALGALARRONDO, M. et al. Chemical and structural characterization of lowdensity lipoproteins purified from hen egg yolk. Food Chem., v.83, p.175-183, 2003.

BENCHARIF, D.; AMIRAT, L.; ANTON, M. et al. The advantages of LDL (Low Density Lipoproteins) in the cryopreservation of canine semen. Theriogenology, v.70, p.1478-1488, 2008.

BENCHARIF, D.; AMIRAT-BRIAND, L.; GARAND, A. et al. Freezing canine sperm: Comparison of semen extenders containing Equex ${ }^{\circledR}$ and LDL (Low density lipoproteins). Anim. Reprod. Sci., v.119, p.305-313, 2010a. 
BENCHARIF, D.; AMIRAT, L.; PASCAL, O. et al. The advantages of Combining Low-density lipoproteins with glutamine for cryopreservation of canine semen. Reprod. Dom. Anim., v.45, p.189-200, $2010 \mathrm{~b}$.

DEMIANOWICZ, W.; STRZEZEK, J. The effect of lipoprotein fraction from egg yolk on some of the biological properties of boar spermatozoa during storage of the semen in liquid state. Reprod. Dom. Anim., v.31, p.279-280, 1996

EVANS, R.J.; BAUER, D.H.; VAGHEFI, S.B. et al. Influence of feeding cottonseed oil to laying hens on the low density lipoproteins of their eggs. J. Nutr., v.99, p.485-490, 1969.

FOULKES, J.A. The separation of lipoproteins from egg yolk and their effect on the motility and integrity of bovine spermatozoa. J. Reprod. Fertil., v.49, p.277284, 1977.

GRANT, D.A.W.; HJERTÉN, S. Some observations on the choice of detergent for solubilization of the human erythrocyte membrane. Biochem. J., v.164, p.465-468, 1977.

HARRIS, E.L.V. Concentration of the extract. In: HARRIS, E.L.V.; ANGAL, S. (Eds), Protein purification methods: a practical approach. New York: IRL, 1992. p.125-161.

HARRISON, R.A.P.; VICKERS, S.E. Use of fluorescent probes to assess membrane integrity in mammalian spermatozoa. J. Reprod. Fertil., v.88, p.343-352, 1990

HU, J-H.; LI, Q-W.; ZAN, L-S. et al. The cryoprotective effect of low-density lipoproteins in extenders on bull spermatozoa following freezingthawing. Anim. Reprod. Sci., v.117, p.11-17, 2010.

JOHNSTON, S.D.; KUSTRITZ, M.V.R.; OLSON, P.N.S. Canine and Feline Theriogenology. Philadelphia: WB Saunders, 2001.

JOLIVET, P.; BOULARD, C.; BEAUMAL, V. et al. Protein components of low-density lipoproteins purified from hem egg yolk. J. Agric. Food Chem., v.54, p.4424-4429, 2006.

JONES, A.R. Metabolic activity of hypotonically treated mature boar spermatozoa. Reprod. Fertil. Develop., v.9, p.583-586, 1997.

KUMI-DIAKA, J. Subjecting canine semen to the hypo-osmotic test. Theriogenology, v.39, p.12791289, 1993.
LARA, A.B.W.H.; NAZÁRIO, G.; ALMEIDA, M.E.W. et al. Normas Analíticas do Instituto Adolfo Lutz. 3.ed. São Paulo: Secretaria de Estado da Saúde, 1976. p.20-21.

LOWRY, O.H.; ROSEBROGH, N.J.; FARR, A.L. Protein measurement with the folin phenol reagent. $J$. Biol. Chem., v.193, p.265-275, 1951.

MARTIN, J.C.; KLUG, E.; GUNZEL, A.R. Centrifugation of stallion semen and its storage in large volume straws. J. Reprod. Fertil., v.27 (suppl 1), p.47-51, 1979.

MOUSSA, M.; MARTINET, V.; TRIMECHE, A. et al. Low density lipoproteins extracted from hen egg yolk by an easy method: cryoprotective effect on frozen-thawed bull semen. Theriogenology, v.57, p.1695-1706, 2002.

MOUSTACAS, V.S.; ZAFFALON, F.G.; LAGARES, M.A. et al. Natural, but not lyophilized, low density lypoproteins were an acceptable alternative to egg yolk for cryopreservation of ram semen. Theriogenology, v.75, p.300-307, 2011.

OBARA, A.; OBIEDZINSKI, M.; KOLCZAK, T. The effect of water activity on cholesterol oxidation in spray- and freeze-dried egg powders. Food Chem., v.95, p.173-179, 2006.

PACE, M.M.; GRAHAM, E.F. Components in egg yolk which protect bovine spermatozoa during freezing. J. Anim. Sci., v.39, p.1144-1149, 1974.

SAMPAIO, I.B.M. Estatística aplicada a experimentação animal. Belo Horizonte: Fundação de Ensino e Pesquisa em Medicina Veterinária e Zootecnia, 2001. 221p.

SCHÄFER-SOMI, S.; KLUGER, S.; KNAPP, E. et al. Effects of semen extender and semen processing on motility and viability of frozen-thawed dog spermatozoa. Theriogenology, v.6, p.173-182, 2006.

VARELA JUNIOR, A.S.; CORCINI, C.D.; ULGUIM, R.R. et al. Effect of low density lipoprotein on the quality of cryopreserved dog semen. Ani. Reprod. Sci., v.115, p.323-327, 2009.

WATSON, P.F. The effects of cold shock on sperm membranes. In: CLARKE, A., MORRIS, G.J. (Eds). Effects of low temperatures on biological membranes. London: Academic Press, 1981. p.189-218. 